\title{
Search for Protein Farnesyltransferase Inhibitors of Microbial Origin: Our Strategy and Results as well as the Results Obtained by Other Groups
}

\author{
Shigeo Iwasaki, Satoshi Ōmura
}

Received: March 10, 2006 / Accepted: December 22, 2006

(C) Japan Antibiotics Research Association

\begin{abstract}
Mutant ras oncogenes are associated with various human tumors, being found in approximately $25 \%$ of all human cancers. Since its identification, the enzyme Ras protein farnesyltransferase (PFTase), which catalyzes the initial step of Ras-processing, has been viewed as a most promising target for cancer therapy. Consequently, a number of synthetic and natural small molecules have been searched and developed according to this concept during the 1990s. Among these, microbial metabolites have provided diverse structural classes of compounds which exhibit PFTase inhibitory activity. This article reviews our work on PFTase inhibitors originating from microbial metabolites, and the results of similar works carried out by several other research groups.
\end{abstract}

Keywords inhibitor of protein farnesyltransferase, microbial metabolites, screening and assay system, gliotoxin, pepticinnamins, andrastins, kurasoins

\section{Introduction}

Three ras proto-oncogenes $(\mathrm{H}, \mathrm{N}$ and $\mathrm{K}$ ) encode four structurally related $21-\mathrm{kDa}$ membrane-associated guaninenucleotide-binding proteins: H-Ras, N-Ras, K-Ras4A and $\mathrm{K}$-Ras4B [1, 2], which play a critical role in the control of cellular proliferation and differentiation. The Ras protein is normally localized in the plasma membrane and extensive post-translational processing must occur for this localization and for the biological activity of Ras to be expressed [3, 4]. The first step in this process is the Ras farnesylation by a protein farnesyltransferase (PFTase) [5]. Since activation of Ras protein by a point mutation is found in a variety of human cancer cells, inhibition of PFTase function has been recognized as a critical target for cancer chemotherapy. The first paper on PFTase inhibitors according to such a concept appeared in 1990, in which inhibitory activities of several substrate analog tetrapeptides containing CAAX sequences, consensus $C$-terminal motif of Ras proteins, were reported [6].

Our research group has undertaken comprehensive studies on bioactive substances of microbial origin by devising various screening methods. The search for inhibitors of Ras farnesylation started at the beginning of 1990s [7] initially in cooperation with Rhone-Poulenc Rorer S. A., and three groups of novel compounds as well as nine groups of compounds previously isolated with other bioactivities were found via this program. This review summarizes the results obtained from our search for PFTase inhibitors of microbial origin, as well as those found by other research groups.

Although recent studies have revealed that PFTase inhibition is not effective in blocking Ras function, being limited only to H-Ras, the results covered in this review were mostly obtained during the initial search for Ras PFTase inhibitors. The present situation on protein PFTase
S. Ōmura (Corresponding author): Kitasato Institute for Life Sciences and Graduate School of Infection Control Sciences, Kitasato University and The Kitasato Institute, 5-9-1, Shirokane, Minato-ku, Tokyo 108-8641, Japan, E-mail: omura-s@kitasato.or.jp
Shigeo Iwasaki: The Kitasato Institute, 5-9-1, Shirokane, Minatoku, Tokyo 108-8641, Japan 
and other protein prenyltransferases will be discussed later.

\section{Protein Farnesyltransferase (PFTase)}

The addition of a farnesyl group to conserved amino acid residues at the carboxy terminus is necessary for the proper functioning of many farnesylated proteins. Ras proteins are GTP/GDP-binding proteins. The GTP-bound conformation is biochemically active and able to transform cells, whereas the GDP-bound state is inactive. The mitogenic activity of normal Ras is modulated by a GDP-GTP cycle. In its GTPbound form, Ras activates several downstream effector pathways that mediate cell proliferation or other effects (Fig. 1).

The Ras oncoprotein p21 must be localized in the plasma membrane in order to function and transform cells. It, however, lacks the conventional transmembrane or hydrophobic domains typical to membrane-associated proteins. To overcome this, farnesylation of Ras by PFTase occurs as the first step in a series of modifications. It occurs in vivo on a cysteine residue at the conserved $C$-terminal tetrapeptide sequence present in all Ras protein to form a thioester linkage $\left(\mathrm{CA}_{1} \mathrm{~A}_{2} \mathrm{X}\right.$ motif $[8,9]$, where $\mathrm{C}=$ cysteine, $\mathrm{A}_{1}, \mathrm{~A}_{2}=$ aliphatic amino acids, $\mathrm{X}=$ serine, leucine, methionine, or glutaminic acid). This farnesylation reaction is then followed by cleavage at the third amino acid from the $C$-terminus to release the $\mathrm{A}_{1} \mathrm{~A}_{2} \mathrm{X}$ sequence, and methylation of resulting carboxy terminal of the cysteine residue (Fig. 2). Interference with Ras farnesylation would alter membrane localization and transforming activity of ras oncogene, and might lead to the development of useful anticancer drugs. Based on this concept, we have screened extensively for PFTase inhibitors from microbial sources.

\section{Screening and Assay Methods for PFTase Inhibitors used in Our Work}

The screening system consisted of two different methods. The first (Method 1) is to use the process of Ras p21 farnesylation by partially purified PFTase directly. The second (Method 2) is to use conjugation between some Saccharomyces cerevisiae haploid cells. In Method 1, PFTase was partially purified from the cytosol of human monocyte THP-1 (ATCC TIB202) [10], and Ha-ras p21 protein was produced in a bacterial expression system and purified as described previously [11]. The method was

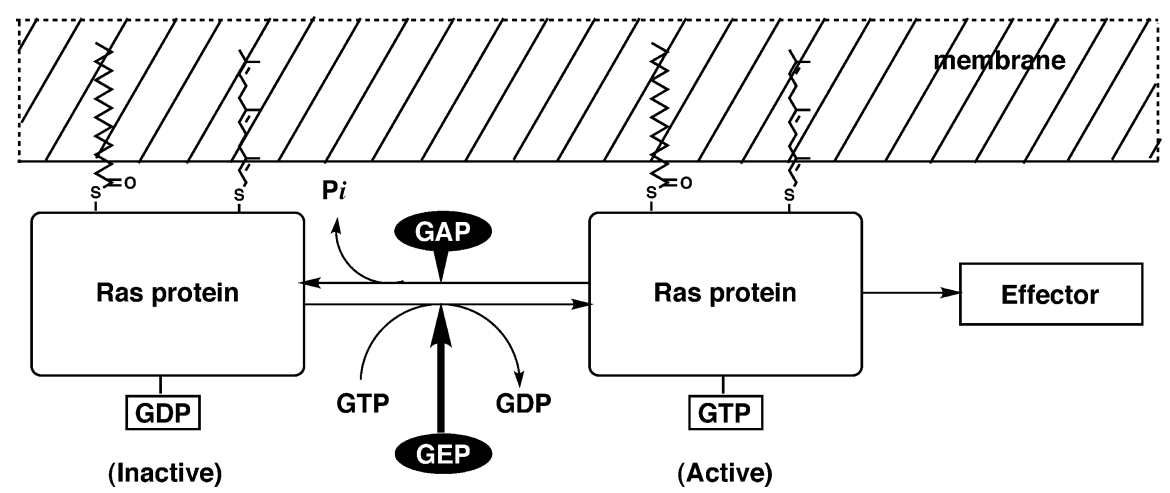

Fig. 1 Model of Ras protein as regulatory proteins (in $\mathrm{H}$ - and $\mathrm{N}$-Ras).

For mambrane targeting by K-Ras, polybasic domain at the $C$-terminus play a role instead of palmitoylation. GDP, guanosine 5'-diphosphate; guanosine 5'-triphosphate, GAP, GTPase activating protein; GEP, GDP/GTP exchange protein.

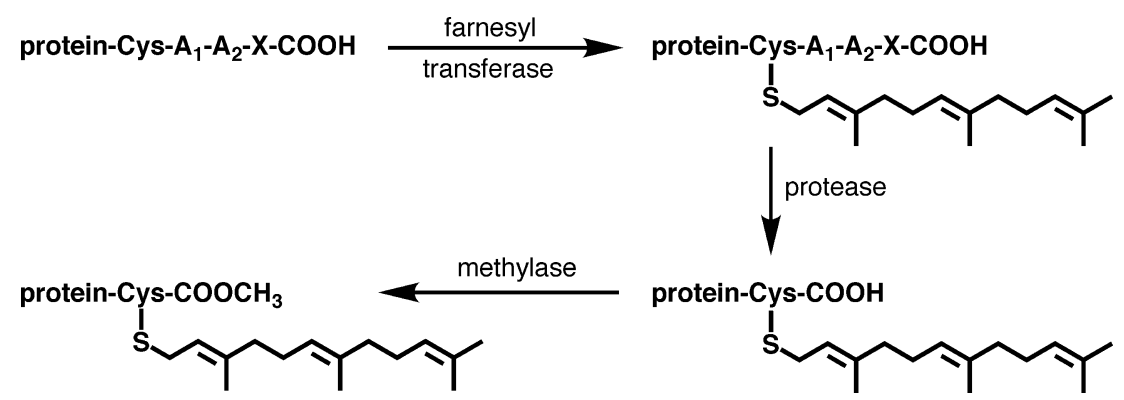

Fig. 2 Post translational modification of the proteins with $C_{1} A_{2} X$ terminal motif.

Cys, cystein; $A_{1}$ and $A_{2}$, any aliphatic amino acid; $X-C O O H$, serine, leucine, methionine or glutamic acid. 


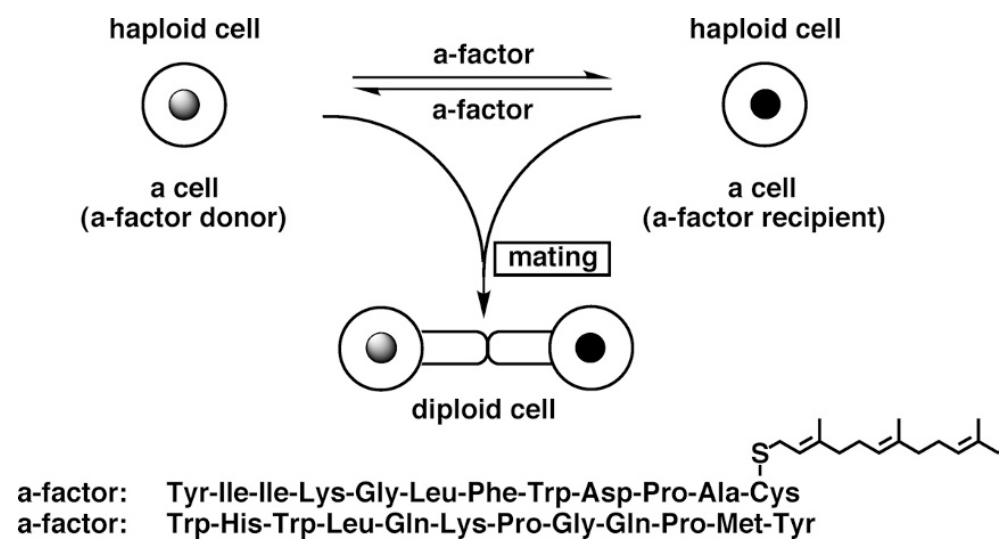

Fig. 3 Concept of $S$. cerevisiae mating assay.
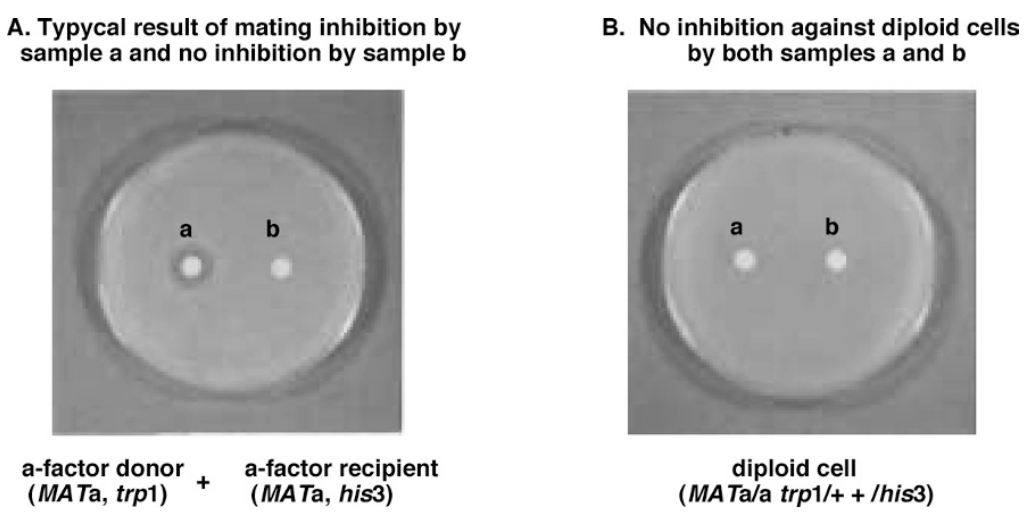

Fig. 4 Conjugation between S. cerevisiae a (MATa) and a (MATa) haploid cells.

utilized both for screening of inhibitors and for evaluation of the samples.

Method 2 was based on the consideration that since some of the PFTase inhibitors screened by Method 1 were found to be inactive in vivo, a screening method using yeast cells was devised as an in vivo model [12]. The reproductive cycle of Saccharomyces cerevisiae includes both haploid and diploid phases. In the haploid phase, two cell types, a and $\boldsymbol{\alpha}$, each secrets specific mating pheromones, known as a- and $\boldsymbol{\alpha}$-factors, respectively. Mating between a- and $\boldsymbol{\alpha}$ haploid cells result in a third cell type, $\mathbf{a} / \boldsymbol{\alpha}$ diploids [13, 14]. The process and the structures of a- and $\boldsymbol{\alpha}$-factors [15] are summarized in Fig. 3. The a-factor peptide is to be $S$ farnesylated at cysteine terminal to function for diploid formation, therefore formation of inhibition zone on the solid culture medium mixed with both haploids, as shown A-a in Fig. 4, may reflect the inhibition of Cys-farnesylation in vivo. The samples screened according to this method were further confirmed by the method 1 .

\section{PFTase Inhibitors Discovered by Our Screening Program}

According to our screening methods to find PFTase inhibitors, three groups of novel compounds including pepticinnamins $A \sim F[16 \sim 18]$, andrastins $A \sim D[19 \sim 22]$ and kurasoins A, B [23, 24] were newly isolated, and nine groups of known compounds including gliotoxin [25] and acetylgliotoxin [26], WS5995C [27], sclerotiorin [28], thysanone and $O$-methylthysanone [29], $\alpha \beta$-dehydrocurvularin [30], granaticins A [31], B [32], penisillic acid [33], spiculisporic acid [34] and citoreohybridones [35] were identified to have PFTase inhibitory activities. Chemical structures of these compounds are shown in Figs. 5 and 6. Their inhibitory activities against PFTase and conjugation between a and $\boldsymbol{\alpha}$ yeasts are summarized in Table 1 .

Although gliotoxin (GT) and acetylgliotoxin (AGT) isolated from the culture of a fungus strain FO2047 [10] were known compounds, they provided one ot the earliest examples (together with 10'desmethoxystreptonigrin) among the PFTase inhibitors discovered from microbial metabolites. GT and AGT inhibited PFTase with $\mathrm{IC}_{50}$ 


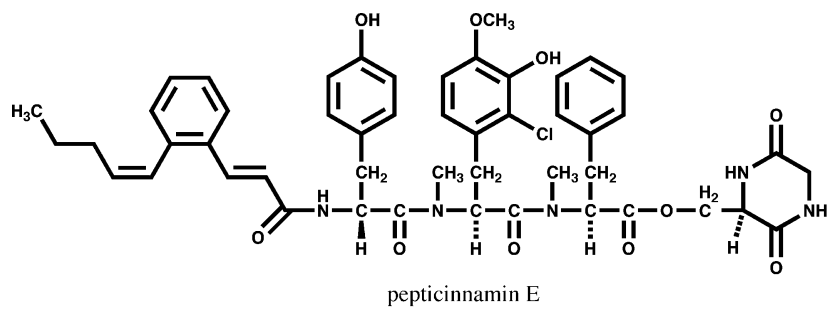<smiles>O=C(Cc1ccccc1)C(O)Cc1ccc(O)cc1</smiles>

kurasoin A

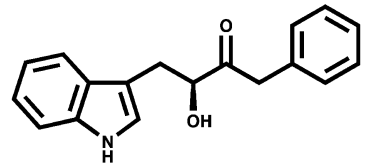

kurasoin B

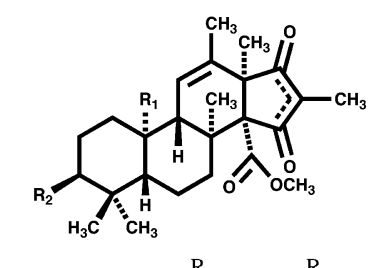

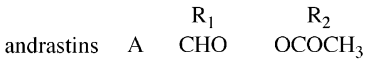

B $\mathrm{CH} 2 \mathrm{OH} \quad \mathrm{OCOCH}_{3}$

$\begin{array}{ccc}\mathrm{C} & \mathrm{CH}_{3} & \mathrm{OCOCH}_{3} \\ \mathrm{D} & \mathrm{CH}_{3} & =\mathrm{O}\end{array}$

Fig. 5 Structures of newly found microbial products identified as PFTase inhibitors by our screening system.

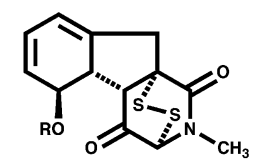

$$
\text { gliotoxin } \quad \mathrm{R}=\mathrm{H}
$$

$$
\begin{array}{ll}
\text { acetylgliotoxin } & \mathrm{R}=\mathrm{CH} 3
\end{array}
$$
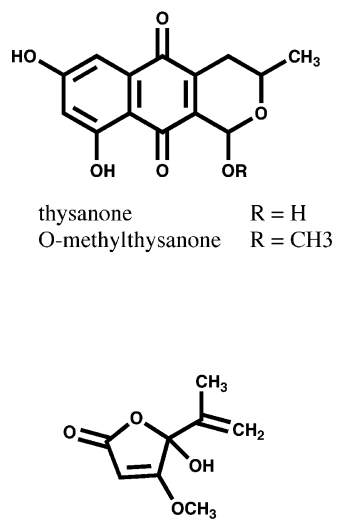

penicillic acid<smiles>Cc1cc(O)c(C2=C(O)C(=O)c3c(O)cccc3C2=O)c(O)c1</smiles>

WS5995C<smiles>Cc1cc(O)cc(O)c1C(=O)/C=C\CCC(C)OC(=O)O</smiles>

ab-dehydrocurvularin

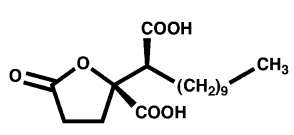

spiculisporic acid
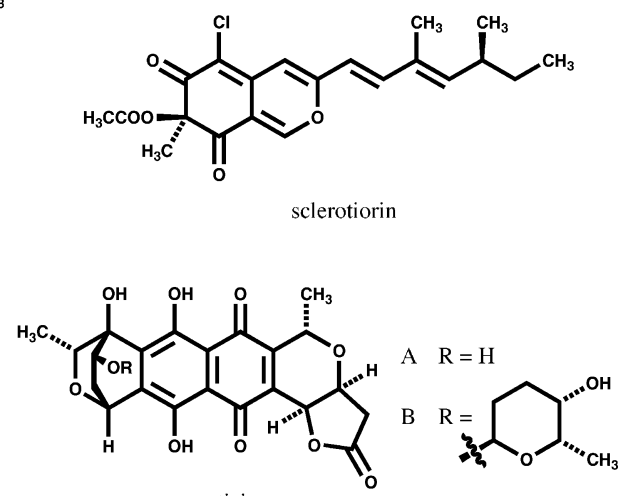

granaticins

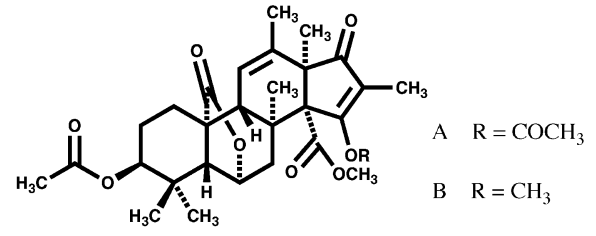

citreohybridones

Fig. 6 Structures of microbial products formerly isolated by other groups and newly identified as PFTase inhibitors by our screening system.

values of $1.1 \mu \mathrm{M}$ and $4.4 \mu \mathrm{M}$, respectively, whereas the tetrapeptide control CVLS ( $\mathrm{NH}_{2}$-Cys-Val-Leu-Ser-COOH), a synthetic PFTase inhibitor which mimics the carboxy terminal sequence of Ha-ras-p21 protein, showed $\mathrm{IC}_{50}$ of $6.6 \mu \mathrm{M}$ by our assay method. Our experiments suggested GT and AGT act via the corresponding reduced dithiol form, however it was found that neither $S$-farnesylation nor competition with the CVLS of these substrates occured. Gliotoxin was originally identified as a mycotoxin possessing antimicrobial activity, for which gliotoxin requires the oxidized form (disulfide form). This fact suggests that the mechanism of PFTase inhibition by this compound is distinct from that of antimicrobial activity [7].

Pepticinnamins A $\sim$ F were isolated from Streptomyces sp. OH-4652. Though their chemical structures remained undetermined except for pepticinnamin E, their PFTase inbitory activities were assayed as shown in Table 1 . Among them pepticinnamin $\mathrm{C}$ showed most potent inhibition $\left(\mathrm{IC}_{50} \sim 100 \mathrm{nM}\right)$, though both cell toxicity and antimicrobial activity of this compound were extremely 
Table 1 PFTase inhibitors of microbial origin discovered by our screening system

\begin{tabular}{|c|c|c|c|}
\hline Compound & $\begin{array}{l}\text { Inhibition of PFTase } \\
\qquad\left(\mathrm{IC}_{50}: \mu \mathrm{M}\right)^{\mathrm{a})}\end{array}$ & $\begin{array}{c}\text { Inhibition of } \mathbf{a} \text { and } \mathbf{a} \\
\text { yeast cells conjugation }\end{array}$ & $\begin{array}{c}\text { Producing } \\
\text { microorganism }^{\text {b) }}\end{array}$ \\
\hline Pepticinnamin A & 0.65 & no & Streptomyces sp. \\
\hline B & 0.2 & no & \\
\hline C & 0.1 & no & \\
\hline D & 1 & no & \\
\hline E & 0.3 & no & \\
\hline $\mathrm{F}$ & 0.5 & no & \\
\hline Andrastin A & 24.9 & yes & Penicillium sp. \\
\hline B & 47.1 & yes & \\
\hline C & 13.3 & yes & \\
\hline Kurasoin A & 58 & no & Paecilomyces sp. \\
\hline B & 65 & no & \\
\hline Gliotoxin & 1.1 & not spcific ${ }^{c l}$ & a fungus sp. \\
\hline Acetylgliotoxin & 4.4 & not spcific ${ }^{c)}$ & \\
\hline WS5995-C $C^{d)}$ & 25.7 & no & Actinomycete sp. \\
\hline Sclerotiorin ${ }^{d)}$ & 14.5 & - & a fungus sp. \\
\hline Thysanone $\mathrm{d}^{\mathrm{d}}$ & 12.2 & yes & Gliocladium sp. \\
\hline 1-O-Methylthysanone ${ }^{\text {d) }}$ & 23.7 & yes & \\
\hline ab-Dehydrocurvularin ${ }^{\mathrm{d})}$ & 48.7 & yes & a fungus sp. \\
\hline Granaticin $A^{d)}$ & 47.3 & yes & Actinomycete sp. \\
\hline$B^{d)}$ & 44.8 & yes & \\
\hline Penicillic acid ${ }^{d)}$ & 25 & no & a fungus sp. \\
\hline Spiculisporic acid ${ }^{d)}$ & 48 & yes & a fungus sp. \\
\hline Citoreohybridone A & 16.8 & - & \\
\hline B & 3.6 & & \\
\hline CVLSe) & 6.6 & & \\
\hline
\end{tabular}

a) ${ } C_{50}$ values determined by Method 1. ${ }^{\text {b) }}$ strains used by our group; ${ }^{c}$ both gliotoxin and acetylgliotoxin inhibit the growth of diploid yeast cells; ${ }^{\text {d) }}$ the data have not been published previously; ${ }^{\text {e) }}$ a synthetic standard inhibitor, $\mathrm{NH}_{2}$-Cys-Val-Leu Ser$\mathrm{COOH}$.

low. The kinetic analysis indicated that pepticinnamin $\mathrm{E}$ inhibits non-competitively with respect to the substrate farnesyl pyrophosphate $(K i, 1.9 \mu \mathrm{M})$ and competitively with p21 ras protein $(K i, 1.76 \mu \mathrm{M})[36]$. Andrastins A $\sim \mathrm{D}$ produced by Penicillium sp. FO-3929 have unique skeletal structure similar to that of citreohybridones reported as antifeedant and insecticidal compounds. Both andrastins and citreohybridones were biosynthesized from a sesquiterpene and a tetraketide units, though they have a common androstane skeleton [21]. Andrastins $\mathrm{A} \sim \mathrm{C}$ and citreohybridones A and B had moderate PFTase inhibitory activities [20]. Among them, citreohybridone B showed most potent inhibition with an $\mathrm{IC}_{50}$ value of $3.6 \mu \mathrm{M}$. When andrastin $\mathrm{C}$ was preincubated with PFTase for 20 minutes before the enzyme assay, the inhibition did not change, suggesting that the compound inhibits PFTase reversibly. Kurasoins A and B were isolated from the culture broth of Paecilomyces sp. FO-3684 in the course of our screening for ATPase inhibitors, though their activities were not remarkable. They showed no antimicrobial activity at $50 \mu \mathrm{g} /$ disk.

Interestingly, manumycin (UCF1-C) and its related compounds were characterized as PFTase inhibitors by a microbial screening using yeast cells [37], and are structurally closely related to asukamycin (Fig. 7) isolated from the culture of Streptomyces sp. by our group [38, 39]. Both manumycin and asukamycin exhibit antibacterial activities against Gram-positive bacteria. Asukamycin was also found to have anticoccidial activity. Furthermore, frenolicin B [40, 41], and nanaomycins A and D [42, 43], formerly isolated in our group from Streptomyces strains as antimycoplasmal and antibacterial compounds, respectively, were recently found to also show PFTase inhibitory activities [44] (for their structures see Fig. 7). These three compounds showed inhibitory activities against bovine brain PFTase with $\mathrm{IC}_{50}$ values of $1.4 \mu \mathrm{M}, 3.2 \mu \mathrm{M}$ and 
<smiles>Cc1c(C(=O)O)nc(-c2ccc3c(n2)C(=O)C(N)=CC3=O)c2[nH]c3ccccc3c12</smiles>

10 '-desmethoxystreptonigrin

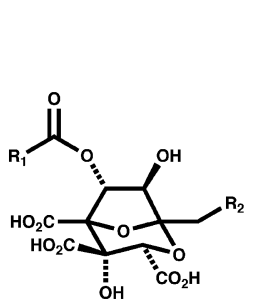

zaragozic acid A-D, D2

$$
\text { D }
$$

A: $\mathrm{H}_{3} \mathrm{C} \overbrace{\mathrm{CH}_{3} \mathrm{CH}_{3}}$

B: $\mathrm{H}_{3} \mathrm{C}$

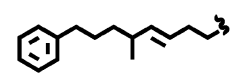

D: $\mathrm{H}_{3} \mathrm{C} \sim{ }^{3}$

D2: $\mathrm{H}_{3} \mathrm{C} \sim 3$<smiles>O=C(P)NC1=CC(O)(/C=C/C=C/C=C/C(=O)NC2=C(O)CCC2=O)C2OC2C1=O</smiles>

$=\overbrace{}^{\mathrm{CH}_{3} \mathrm{CH}_{3}} \mathrm{CH}_{3}$ UCF1-A $\underbrace{\mathrm{CH}_{3} \mathrm{CH}_{3}}_{\text {UCF1-B }} \mathrm{CH}_{3}$ $\mathrm{CH}_{3} \mathrm{CH}_{3} \mathrm{CH}_{3}$

C $\mathrm{CH}_{3}^{\mathrm{UCF1}-\mathrm{C}}$ asukamycin<smiles>[R8]C1=COc2oc3cc(Br)cc(O)c3c(=O)c2C(C(=O)OC)=C1</smiles>

fusidienol $\quad \mathrm{R}_{1}=\mathrm{CH}_{2} \mathrm{OH}, \mathrm{R}_{2}=\mathrm{H}$ fusidienol $\mathrm{A} \quad \mathbf{R}_{1}=\mathrm{H}, \mathrm{R}_{2}=\mathrm{CH}_{3}$

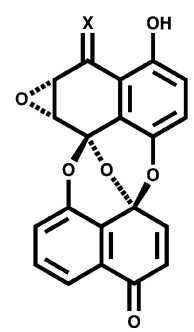

preussomerin D: $\mathrm{X}=\mathrm{H}, \mathrm{OH}$ preussomerin $\mathrm{G}: \mathrm{X}=\mathrm{O}$
$\mathbf{R}_{2}$

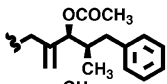<smiles>CCC(C)C(O)C(C)CCC=C1C=CC=C1</smiles>

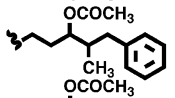<smiles>CCCCC(CC=Cc1ccccc1)C(C)OC</smiles>
$3 \sim \mathrm{CH}_{1}$<smiles>CC(C(=O)O)=C(CC(C)(C)CC(C)(C)C)C(=O)O</smiles><smiles>CCC(C)/C=C\CCCC(C)(C)C/C(C(=O)O)=C(\C)C(=O)O</smiles>

chaetomellic acid $B$

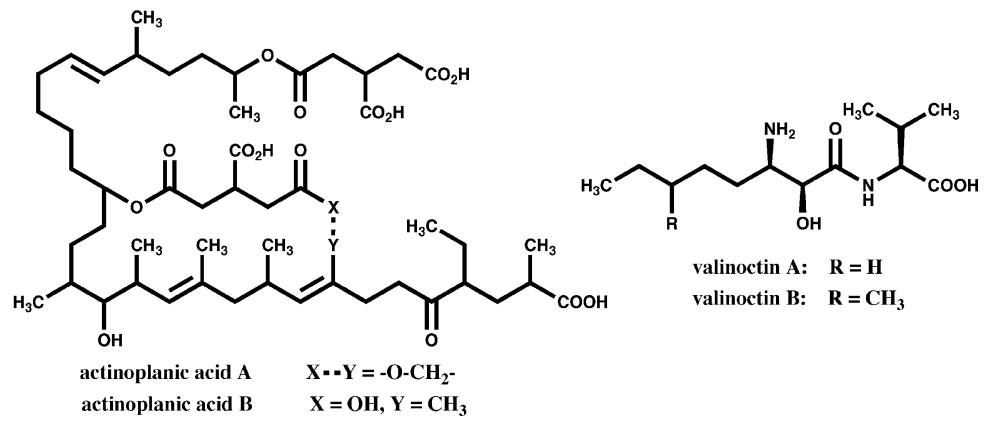<smiles>COc1cc(O)c(Oc2cc(C)cc(O)c2C(=O)O)c(CO)c1</smiles>

barceloneic acid $\mathrm{A}$

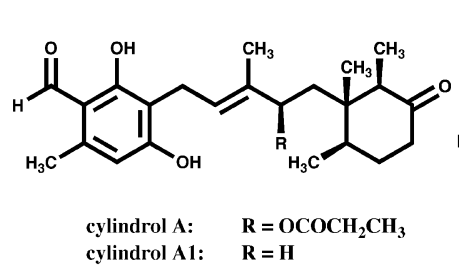
cylindrol A1: $\quad \mathbf{R}=\mathbf{H}$

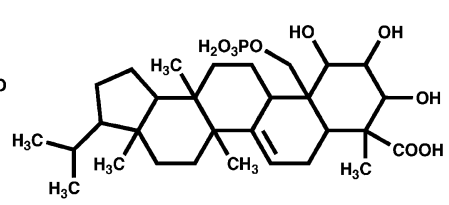

RPR113228<smiles>CCC(C)(O)CC1=C2C(=O)C3(CC1)C1OC23c2cccc(OC)c21</smiles>

Sch $\mathbf{5 8 4 5 0}$<smiles>O=C(O)CCC(CC(=O)O)=C(CCC(=O)O)C(=O)O</smiles><smiles>C[C@H](CCC(O)C(C)(C)O)C1CC[C@]2(C)C3=C(CC[C@]12C)[C@@]1(C)C[C@H](CC(=O)CC(C)(O)CC(=O)O)C(=O)C(C)(C)[C@]1(C)CC3</smiles><smiles>O=Cc1cc(O)c(C=O)c(C(=O)c2cccc(O)c2O)c1</smiles>

Sch 207278

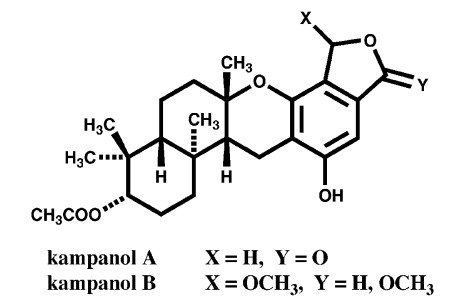

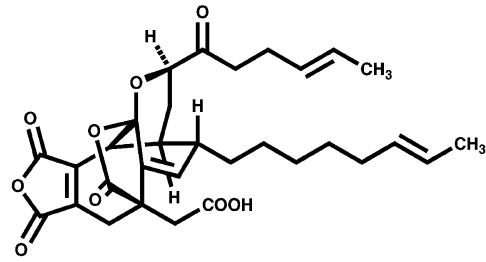

CP-263,114

CP-225,917

Fig. 7-1 Structures of PFTase inhibitors of microbial origin found by other groups. 
<smiles>CCC(/C=C/C=C/C=C/C[C@H](OC(=O)C1(NC(=O)C2CCCCC2)CC1)[C@@H](C)[C@@H](O)/C(C)=C\CCC1=CC(=O)C=C(NC(=O)CC(OC)OC)C1=O)OC</smiles>

UCF116-A<smiles>C=C[C@H](CCCCC)C1=C(C(=O)C2C(C)C=C[C@]3(O)CC(=O)CC(C)C23)C(=O)NC1=O</smiles>

TAN-1813

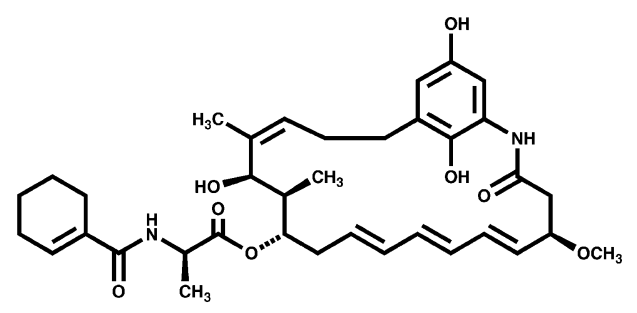

UCF116-B<smiles>CCC1O[C@@H]2CC(=O)O[C@H]2C12OC21C(=O)c2cccc(O)c2C(=O)[C@H]1CC</smiles>

UCF76-B<smiles>CCC1O[C@@H]2CC(=O)O[C@H]2C2=C1C(=O)c1c(O)cccc1C2=O</smiles>

UCF76-C (frenolicin B)<smiles>CC1OC(CC(=O)O)CC2=C1C(=O)c1c(O)cccc1C2=O</smiles>

nanaomycin A<smiles>CC1OC2CC(=O)OC2C2=C1C(=O)c1c(O)cccc1C2=O</smiles>

nanaomycin D<smiles>C[C@H]1O[C@@H]2CC(=O)O[C@@H]2C2=C1C(=O)c1c(O)cccc1C2=O</smiles>

kalafungin

Fig. 7-2 Structures of PFTase inhibitors of microbial origin found by other groups. (Continued)

Table 2 Chronology of the discovery of PFTase inhibitors of microbial origin

\begin{tabular}{|c|c|}
\hline Year & Compound name \\
\hline 1992 & gliotoxin $^{\mathrm{b})} ;$ acetylgliotoxin $^{\mathrm{b})} ; 10^{\prime}$-desmethoxystreptonigrin \\
\hline 1993 & $\begin{array}{l}\text { pepticinnamins } \mathbf{A} \sim \mathbf{F}^{\mathrm{a})} \text {; } \mathbf{W S}_{\mathbf{5 9 9 5}}{ }^{\mathrm{b}), \mathrm{d})} \text {; } \text { sclerotiorin }^{\mathrm{b}) \text {,d); }} \text {; chaetomeric acids } A, B \text {; zaragozic acids } A \sim D \text {, } \\
\mathrm{D}_{2} ; \text { UCF1-A, B, C (manumycin) }\end{array}$ \\
\hline 1994 & 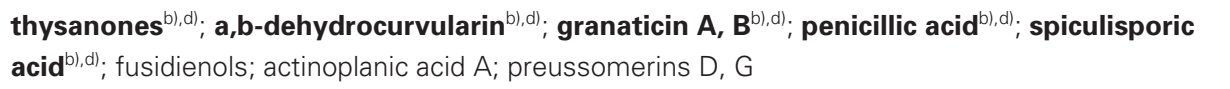 \\
\hline 1995 & valinoctins A, B; barcelonic acid A; cylindrols A, B; RPR113228; Sch 58450 \\
\hline 1996 & andrastins $\mathbf{A} \sim \mathbf{D}^{\mathrm{a})}$; citreohybridones $\mathbf{A}, \mathbf{B}^{\mathrm{b})}$; kurasoins $\mathbf{A}, \mathbf{B}^{\mathrm{a})}$; oreganic acid $\mathrm{A}$ \\
\hline 1997 & CP-225917, -263114; Sch 207278 \\
\hline 1998 & clavaric acid; kampanols A, B \\
\hline 1999 & - \\
\hline 2000 & UCF116-A, B; TAN-1813 \\
\hline 2001 & UCF76-A, B, C (frenolicin $\mathbf{B}^{\mathrm{c})}$ ); nanaomycins $\mathbf{A}$, $\mathbf{D}^{\mathrm{c}}$; kalafungin \\
\hline
\end{tabular}

In bold are the compounds from our group: a) PFTase inhibitors newly found using our screening system; ${ }^{\text {b) }}$ formerly isolated by other group and newly identified as PFTase inhibitor by our screening system; ' ${ }^{c}$ isolated by us and identified as PFTase inhibitors by another group; ${ }^{\text {d) }}$ previously unpublished PFTase inhibitors.

$1.9 \mu \mathrm{M}$, respectively.

\section{PFTase Inhibitors Discovered by Other Groups}

As mentioned previously, we initiated the search for the inhibitors of PFTase of microbial origin at the initial stage of work in this field, along with several other groups, as is clearly indicated in the chronological table of PFTase inhibitor discoveries from microbial products (Table 2). The structures of the compounds discovered are shown in Fig. 7 and reported respective PFTase inhibitory activities 
Table 3 PFTase inhibitors of microbial origin discovered by other group

\begin{tabular}{|c|c|c|c|c|}
\hline Compound name & $\begin{array}{l}\text { PFTase inhibit. } \\
\text { activity }\left(\mathrm{IC}_{50}: \mu \mathrm{M}\right)\end{array}$ & $\begin{array}{c}\text { FPP acceptor peptide } \\
\text { used }\end{array}$ & $\begin{array}{l}\text { Producing } \\
\text { microorganism }\end{array}$ & Ref.* \\
\hline $\begin{array}{c}10^{\prime} \text {-desmethoxy- } \\
\text { streptonigerin }\end{array}$ & 2.1 & Ras p21 & Streptomyces sp. & 49 \\
\hline Chaetomeric acid $\mathrm{A}$ & $0.055^{\mathrm{a})}$ & Ras-CVIM & Chaetomella sp. & 50 \\
\hline B & $0.185^{\mathrm{a})}$ & & & \\
\hline Zaragozic acid A & $0.25^{a)}$ & Ras-CVLS & Amauroascus sp. & 51 \\
\hline B & $1.0^{\mathrm{a})}$ & & & \\
\hline $\mathrm{C}$ & $0.15^{\mathrm{a})}$ & & & \\
\hline $\mathrm{D}$ & $0.1^{\text {a) }}$ & & & \\
\hline $\mathrm{D}_{2}$ & $0.1^{\mathrm{a})}$ & & & \\
\hline UCF1-A & $13.0^{\mathrm{b})}$ & Ras 2CTI & Streptomyces sp. & 37 \\
\hline B & $7.0^{\mathrm{b})}$ & & & \\
\hline C (manumycin) & $5.0^{b)}$ & & & \\
\hline Fusidienol & $2.7^{\mathrm{a})}$ & Ras-CVLS & Fusidium sp. & 52 \\
\hline$-A$ & $1.8^{\mathrm{a})}$ & & Phoma sp. & 53 \\
\hline Actinoplanic acid A & $0.23^{c)}$ & Ras-CVIM & Actinoplanes sp. & 54,55 \\
\hline B & $0.05^{c)}$ & & & \\
\hline Pressomerin D & $1.2^{\mathrm{al}}$ & Ras p21 & Preussia sp. & 56 \\
\hline $\mathrm{G}$ & $1.2^{\mathrm{a})}$ & & & \\
\hline Valinoctin A & $0.9^{a)}$ & Hexapeptide & Streptomyces sp. & 57 \\
\hline B & $1.0^{\mathrm{a})}$ & (Takara Shuzo co.) & & \\
\hline Barceloneic acid A & $40.0^{c)}$ & $\begin{array}{l}\text { Ras-CVLS, -CVIM or } \\
\text {-CVLS }\end{array}$ & Phoma sp. & 58 \\
\hline Cylindrol A & $2.2^{a)}$ & Ras p21 & Cylindrocarpon sp. & 59,60 \\
\hline$A_{1}$ & $0.7^{\mathrm{a})}$ & & & \\
\hline RPR113228 & $2.1^{\mathrm{cl}}$ & Ras p21 & Chrysosporium sp. & 61 \\
\hline Sch 58450 & $29.0^{c)}$ & Biotin-KTKCVIM & Streptomyces sp. & 62 \\
\hline Oreganic acid $A$ & $0.014^{c)}$ & Ras-CVIM or -CVLS & a fungus sp. & 63,64 \\
\hline CP-225917 & $6.0^{\mathrm{b})}$ & H-Ras & a fungus sp. & 65 \\
\hline-263114 & $20.0^{\mathrm{bl}}$ & & (Phoma sp.?) & \\
\hline Sch 207278 & $3.5^{\mathrm{c})}$ & $?$ & a fungus sp. & 66 \\
\hline Clavaric acid & $1.3^{\mathrm{cl}}$ & Ras-CVIM or -CVLS & Clavariadelphus sp. & 67 \\
\hline Kampanol A & $13.0^{c)}$ & $?$ & Stachyborys sp. & 68 \\
\hline$B$ & $7.0^{c)}$ & & & \\
\hline UCF116-A & $1.2^{\mathrm{a})}$ & Ras p21 & Streptomyces sp. & 69 \\
\hline$-B$ & $0.6^{\mathrm{a})}$ & & & \\
\hline TAN-1813 & $50.0^{\mathrm{bl}}$ & Biotin-K-Ras & Phoma sp. & 70 \\
\hline UCF76-A & $3.7^{\mathrm{a})}$ & Ras p21 & Streptomyces sp. & 44 \\
\hline$-B$ & $25.0^{\mathrm{al}}$ & & & \\
\hline$-C($ frenolicin B) & $1.4^{\mathrm{a})}$ & & & \\
\hline Nanaomycin A & $3.2^{a)}$ & Ras p21 & Streptomyces sp. & 44 \\
\hline D & $1.9^{\mathrm{a})}$ & & & \\
\hline Kalafungin & $1.7^{\mathrm{a})}$ & Ras p21 & Streptomyces sp. & 71,44 \\
\hline
\end{tabular}

* Ref.; Reference. Origin of the PFTase used for assay: ${ }^{\text {a) }}$ bovine brain; ${ }^{\text {b) }}$ rat brain; ${ }^{\text {c }}$ human recombinant.

as well as the producing organisms are listed in Table 3 . Some of the results, including ours, have been discussed in previously published reviews $[45,46]$. It should be noted that the values of PFTase inhibitory activities shown in Table 3 are not directly comparable for all cases, because they were obtained by several different methods using different enzyme sources and different acceptor peptides. These are summarized in the Table 3. In many reports, the biological activities of respective compounds were also discussed in connection with PFTase specificity and other 
activities such as the effects on geranyl-geranyl transferase, squalene synthase and tumor cells. Literatures cited in Table 3 should be referred to for further information.

\section{Discussion}

Mutant ras oncogenes are associated with unregulated cellular growth. Mutation of Ras protein is found to be one of the most common genetic abnormalities, found in approximately $25 \%$ of all human cancers. Mutation in KRas is prevalent in some epithelial cancers, including pancreatic cancer $(>90 \%)$, colorectal cancer $(\sim 50 \%)$, and lung cancer $(\sim 30 \%)$. Mutation in N-Ras occurs in melanoma (10 20\%) and some hematologic malignancies. Mutation in H-Ras is rare $(15 \sim 20 \%)[1,2]$. This high prevalence made Ras an attractive target for cancer chemotherapy. Several potential strategies for interfering with Ras function have been investigated and the development of a farnsyltransferase inhibitor was initially driven by the desire to inhibit Ras. However, current evidence suggests that the anticancer activity of PFTase inhibitors is not simply due to Ras inhibition [47, 48].

Mammalian cells express three protein prenyltransferases; protein farnesyl-transferase (PFTase), geranylgeranyltransferase-1 (GGTase-1) and geranylgeranyl-transferase-2 (GGTase-2). In addition to Ras, several protein substrates of farnesyltransferase, are critical intermediates of cell signaling and cytoskeletal organization [47, 48].

Recent studies have clarified that functions of K-Ras4B and N-Ras are not affected by PFTase inhibitors, as they can be alternatively prenylated by geranyl geranylation. Since it is K-ras that is usually mutated in human cancer, PFTase inhibitors were ineffective in binding ras-induced cancer. Current understanding is that the effects of PFTase on human cancer are mediated by inhibition of farnesylated by the inhibition of farnesylated proteins other than Ras such as Rheb, pRL3 and CENP-E, F.

A number of studies have been undertaken to find or create PFTase inhibitors, including synthetic analogs of the CAAX sequence or of farnesyl pyrophosphate (FPP) as well as the natural products with structures resembling neither the CAAX motif nor FPP [45]. As summarized in this review, the PFTase inhibitors of microbial origin reported have amounted to almost 40 compound types and 60 individual substances, and the producing microorganisms range from fungi to actinomycetes of very different taxa. This suggests that, although none of the compounds have yet been practically used in chemotherapy, microorganisms will continue to be attractive potential sources of PFTase inhibitors.
Acknowledgement We are grateful to Prof. Kazuro Shiomi, Dr. Junji Inokoshi and Dr. Ryuji Uchida for their kind help in preparation of this manuscript.

References

1. Bos JL. ras oncogenes in human cancer: a review. Cancer Res 49: 4682-4689 (1989)

2. Barbacid M. ras genes. Ann Rev Biochem 56: 779-827 (1987)

3. Gibbs JB. Ras C-Terminal processing enzymes-new drug targets? Cell 65: 1-4 (1991)

4. Khosravi FR, Cox AD, Kato K, Der CJ. Protein prenylation: key to ras function and cancer intervention? Cell Growth Diff 3: 461-469 (1992)

5. Kato K, Cox AD, Hisaka MM, Graham SM, Buss JE, Der CJ. Isoprenoid addition to Ras protein is the critical modification for its membrane association and transforming activity. Proc Natl Acad Sci USA 89: 6403-6407 (1992)

6. Reiss Y, Goldstein JL, Seabra MC, Casey PJ, Brown MS. Inhibition of purified p21 Ras farnesyl: protein transferase by Cys-AAX tetrapeptide. Cell 62: 81-88 (1990)

7. Ōmura S, Takeshima H. Farnesy-protein transferase inhibitors. Drugs of the Future 19: 751-755 (1994)

8. Reiss Y, Stradley SJ, Gierasch LM, Brown MS, Goldstein JL. Sequence requirement for peptide recognition by rat brain p $21^{\text {ras }}$ protein farnesylation. Proc Natl Acad Sci 88: 732-736 (1991)

9. Moores SL, Schaber MD, Mosser SD, Rands E, O'Hara MB, Garsky VM, Marshall MS, Pompliano DL, Gibbs JB. Sequence dependence of protein isoprenylation. J Biol Chem 266: 14603-14610 (1991)

10. Van der Pyl D, Inokoshi J, Shiomi K, Yang H, Takeshima H, Ömura S. Inhibition of farnesyl-protein transferase by gliotoxin and acethylgliotoxin. J Antibiot 45: 1802-1805 (1992)

11. Rey I, Soubigou P, Debussche L, David C, Morgat A, Bost PE, Mayaux JF, Tocque B. Antibody to synthetic peptide from the residue 33 to 42 domain of c-Ha-ras p21 block reconstitution of the protein with different effectors. Mol Cell Biol 9: 3904-3910 (1989)

12. Abe K, Kusaka I, Fukui S. Morphological change in the early stage of the mating process of Rhodosporidium turuloides. J Bacteriol 122: 710-718 (1975)

13. Betz R, Manney TR, Duntze W. Hormonal control of gametogenesis in the yeast Saccharomyces cerevisiae. Gamete Res 4: 571-581 (1981)

14. Miyajima I, Nakafuku M, Nakayama N, Brenner C, Miyajima A, Kaibuchi K, Arai K, Kajiro Y, Matsumoto K. GPA1, a haploid-specific essential gene, encodes a yeast homolog of mammalian $\mathrm{G}$ protein which may be involved in mating factor signal transduction. Cell 50: 1011-1019 (1987)

15. Anderegg RJ, Betz R, Carr SA, Crabb JW, Duntze W. 
Structure of Saccharomyces cerevisiae mating-hormone afactor. J Biol Chem 263: 18236-18240 (1988)

16. Ōmura S, Van der Pyl D, Inokoshi J, Shiomi K, Takahashi Y, Takeshima H. Pepticinnamins, new farnesyl-protein transferase inhibitors produced by an actinomycete. I. Producing strain, fermentation, isolation and biological activity. J Antibiot 46: 222-228 (1993)

17. Shiomi K, Yang H, Inokoshi J, Van der Pyl D, Nakagawa A, Takeshima H, Ōmura S. Pepticinnamins, new farnesylprotein transferase inhibitors produced by an actinomycete. II. Structural elucidation of pepticinnamin E. J Antibiot 46: 229-234 (1993)

18. Hinterding $\mathrm{K}$, Hagenbuch $\mathrm{P}$, Retey J, Waldmann $\mathrm{H}$. Synthesis and in vitro evaluation of the Ras farnesyltransferase inhibitor pepticinnamin E. Angew Chem Int Ed 37: 1236-1239 (1998)

19. Shiomi K, Uchida R, Inokoshi J, Tanaka H, Iwai Y, Ōmura S. Andrastins $\mathrm{A} \sim \mathrm{C}$, new protein farnesyltransferase inhibitors produced by Penicillium sp. FO-3929. Tetrhedron Lett 37: 1265-1268 (1996)

20. Ōmura S, Inokoshi J, Uchida R, Shiomi K, Masuma R, Kawakubo T, Tanaka H, Iwai Y, Kosemura S, Yamamura S. Andrastins $\mathrm{A} \sim \mathrm{C}$, new protein farnesyltransferase inhibitors produced by Penicillium sp. FO-3929. I. Producing strain, fermentation, isolation, and biological activities. J Antibiot 49: 414-417 (1996)

21. Uchida R, Shiomi K, Inokoshi J, Sunazuka T, Masuma R, Tanaka H, Iwai Y, Takayanagi H, Ōmura S. Andrastins $\mathrm{A} \sim \mathrm{C}$, new protein farnesyltransferase inhibitors produced by Penicillium sp. FO-3929. II Structure elucidation and biosynthesis. J Antibiot 49: 418-424 (1996)

22. Uchida R, Shiomi K, Inokoshi J, Sunazuka T, Tanaka H, Iwai Y, Ōmura S. Andrastin D, novel protein farnesyltransferase inhibitor produced by Penicillium sp. FO3929. J Antibiot 49: 1278-1280 (1996)

23. Uchida R, Shiomi K, Inokoshi J, Masuma R, Kawakubo T, Tanaka H, Iwai Y, Ōmura S. Kurasoins A and B, new protein farnesyltransferase inhibitors produced by Paecilomyces sp FO-3684. I. Producing strain, fermentation, isolation, and biological activities. J Antibiot 49: 932-934 (1996)

24. Uchida R, Shiomi K, Sunazuka T, Inokoshi J, Nishizawa A, Hirose T, Tanaka H, Iwai Y, Ōmura S. Kurasoins A and B, new protein farnesyltransferase inhibitors produced by Paecilomyces sp. FO-3684. II. Structure elucidation and total synthesis. J Antibiot 49: 886-884 (1996)

25. Betina U. $(E d)$ Mycotoxin-production, isolation, separation and purification. pp. 351-385 (1984) Elsevier Science Publishing.

26. Johnson JR, Kidwai AR, Warner JS. J Am Chem Soc 75: 2110-2112 (1953)

27. Ikushima H, Okamoto M, Tanaka H, Ohe O, Kohsaka A, Aoki H, Imanaka HJ. New anticoccidial antibiotics, WS$5995 \mathrm{~A}$ and B. Isolation and characterization. J Antibiot 33: 1107-1113 (1980)

28. MacCurtin T, Reilly J. Sclerotiorine, a chlorinated metabolic product of Peniccillium sclerotiorum, Van Beyma. Biochem J 34: 1419-1421 (1940)

29. Singh SB, Cordingley MG, Ball RG, Smith JL, Dombrowski AW, Goetz MA. Structure and stereochemistry of thysanone: a novel human rhinovirus 3C-protease inhibitor from Thysanophora penicilloides. Tetrahedron Lett 32: 5279-5282 (1991)

30. Munro HD, Musgrave OC, Templeton R. Curvularinan. V. Compound $\mathrm{C}_{16} \mathrm{H}_{18} \mathrm{O}_{5}, \alpha, \beta$-dehydroculvularin. J Chem Soc (C) 947-948 (1967)

31. Gorbaz R, Fettinger L, Gauemann E, Kalvoda J, KellerSchierlein W, Kradolfer F, Manukian BK, Neipp L, Prelog V, Reusser P, Zaener H. Stoffwechselprodukte von Actinomyceten. 9. Mitt. Granaticin. Helv Chim Acta 40: 1262-1269 (1957)

32. Barcza S, Brufani M, Keller-Schierlein W, Zaener H. Metabolic products of microorganisms. 52. Granaticin B. Helv Chim Acta 49: 1736-1740 (1966)

33. Birkinshaw JA, Oxford AE, Baistrick H. Studies in the biochemistry of micro-oranisms XLVIII. Penicillic acid, a metabolic product of Penicillium puberulum Bainier and $P$. cyclopium Westling. Biochem J 30: 394-411 (1936)

34. Asano M, Kameda U. Constitution of spiculisporic acid, a metabolic product of Penicillium spiculisporum Lehman. Yakugaku Zasshi 61: 80-86 (1941)

35. Kosemura S, Matsunaga K, Yamamura S, Kubota M, Ohba S. The structure of citreohybridones A and B. Novel sesterterpenoid-type metabolites of hybrid strain KO0031 derived from Punicillium citreo-viride B. IFO 6200 and 4692. Tetrahedron Lett 32: 3543-3546 (1991)

36. Ōmura S, Tomoda H. Microbial metabolites affecting lipid biosynthesis. Pure \& Appl Chem 66: 2267-2270 (1994)

37. Hara M, Akasaka K, Akinaga S, Okabe M, Nakano H, Gomez R, Wood D, Uh M, Tamanoi F. Identification of Ras farnesyltransferase inhibitors by microbial screening. Proc Natl Acad Sci USA 90: 2281-2285 (1993)

38. Ōmura S, Kitao C, Tanaka H, Oiwa R, Takahashi Y, Nakagawa A, Shimada M, Iwai Y. A new antibiotic, asukamycin, produced by Streptomyces. J Antibiot 29: 876-881 (1976)

39. Kakinuma K, Ikekawa N, Nakagawa A, Ōmura S. The structure of asukamycin, a possible shunt metabolite from 3dehydroquinic acid in the shikimate pathway. J Am Chem Soc 101: 3402-3404 (1979)

40. Iwai Y, Kora A, Takahashi Y, Hayashi T, Awaya J, Masuma R, Oiwa R, Ōmura S. Production of deoxyfrenolicin and a new antibiotic, frenolicin B by Streptomyces roseofulvus strain AM-3867. J Antibiot 31: 959-965 (1978)

41. Ōmura S, Tsuzuki K, Iwai Y, Kishi M, Watanabe S, Shimizu H. Anticoccidial activity of frenolicin B and its derivatives. J Antibiot 38: 1447-1448 (1985)

42. Ōmura S, Tanaka H, Koyama Y, Oiwa R, Katagiri M, Awaya J, Nagai T, Hata T. Nanaomycins A and B, new antibiotics produced by a strain of Streptomyces. J Antibiot 27: 363-365 (1974) 
43. Ōmura S, Tanaka H, Okada Y, Marumo H. Isolation and structure of nanaomycin D, an enantiomer of kalafungin. J Chem Soc Chem Comm 320-321 (1976)

44. Hara M, Soga S, Shono K, Eishima J, Mizukami T. UCF76 compounds, new inhibitors of farnesyltransferase produced by Streptomyces. J Antibiot 54: 182-186 (2001)

45. Ayral-Kaloustian S, Salaski EJ. Protein farnesyltransferase inhibitors. Curr Med Chem 9: 1003-1032 (2002)

46. Vilella D, Sanchez M, Platas G, Salazar O, Genilloud O, Royo I, Cascales C, Martin I, Diez T, Silverman KC, Lingham RB, Singh SB, Jayasuriya H, Pelaez F. Inhibitors of farnesylation of Ras from a microbial natural products screening program. J Ind Microbiol Biotech 25: 315-327 (2000)

47. Haluska P, Dy GK, Adjei AA. Farnesyl transferase inhibitors as anticancer agents. Eur J Cancer 38: 1685-1700 (2002)

48. Basso AD, Kirschmeier P, BishopWR. Farnesyl transferase inhibitors. J Lipid Res 47: 15-31 (2006)

49. Liu WC, Barbacid M, Bulgar M, Clark JM, Crosswell R, Dean L. Doyle TW, Fernandes PB, Huang S, Manne V, Pirnik DM, Wells JS, Meyers E. 10'-Desmethoxystreptonigrin, a novel analog of streptonigrin. J Antibiot 45: 454-457 (1992)

50. Gibbs JB, Pompliano DL, Mosser SD, Rands E, Lingham RB, Singh SB, Scolnick EM, Kohl NE, Oliff A. Selective inhibition of farnesyl-protein transferase blocks Ras processing in vivo. J Biol Chem 268: 7617-7620 (1993)

51. Dufresne D, Wilson KE, Singh SB, Zink DL, Bergstrom JD, Rew D, Polishook JD, Meinz M, Huang L, Silverman KC, Lingham RB. Zaragozic acid $\mathrm{D}$ and $\mathrm{D}_{2}$ : Potent inhibitors of squalen synthase and of Ras farnesyl-protein transferase. J Nat Prod 56: 1923-1929 (1993)

52. Singh SB, Johns ET, Goetz MA, Bills GF, Nallin-Omstead M, Jenkins RG, Lingham RB, Silverman KC, Gibbs JB. Fusidienol: A novel inhibitor of Ras farnasyl-protein transferase from Fusidium griseum. Tetrahedron Lett 35: 4693-4696 (1994)

53. Singh SB, Ball RG, Zink DL, Monagham RL, Polishook JD, Sanchez M, Pelaez F, Silverman KC, Lingham RB. Fusidienol A: A novel Ras farnasyl-protein transferase inhibitor from Phoma sp. J Org Chem 62: 7485-7488 (1997)

54. Singh SB, Liesch JM, Lingham RB, Goetz MA, Gibbs JB. Actinoplanic acid A: A macrocyclic polycarboxylic acids which is a potent inhibitor of Ras farnesyl-protein inhibitor. J Am Chem Soc 116: 11606-11607 (1994)

55. Singh SB, Liesch JM, Lingham RB, Silverman KCG, Goetz MA. Structure, chemistry, and biology of actinoplanic acids: Potent inhibitors of Ras farnesyl-protein transferase. J Org Chem 62: 7896-7910 (1997)

56. Singh SB, Zink DL, Liesch JM, Ball RG, Goetz MA, Bolessa EA, Giacobbe RA, Silverman KC, Bills GF, Pelaez F, Cascales C, Gibbs JB, Lingham RB. Preussomerins and deoxypreussomerins: Inhibitors of Ras farnesyl-protein transferase. J Org Chem 59: 6296-6302 (1994)
57. Sekizawa R, Iinuma H, Muraoka Y, Naganawa H, Kinoshita N, Nakamura H, Hamada M, Takeuchi T, Umezawa K. Valinoctins A and B, from Streptomyces strain MJ858-NF3. J Nat Prod 59: 232-236 (1995)

58. Jayasuriya H, Ball RG, Zink DL, Smith J, Goetz MA, Jenkins BG, Hallin-Omstead M, Silverman KC, Bills GF, Lingham RB, Singh SB. Barceloneic acid A: A new farnasyl-protein transferase inhibitor from a Phoma sp. J Nat Prod 56: 986-991 (1995)

59. Singh SB, Zink DL, Bills CF, Cascales C, Jenkins RG, Silverman KC, Lingham RG. Cylindols A: A novel inhibitor of Ras farnasyl-protein transferase from Cylindrocarpon licidum. Tetrahedron Lett 36: 4935-4938 (1995)

60. Singh SB, Ball RG, Bills CF, Cascales C, Gibbs JB, Goetz MA, Hoogsteen K, Jenkins RG, Liesch JM, Lingham RB, Silverman KC, Zink DL. Chemistry and biology of cylindrols: Novel inhibitors of Ras farnasyl-protein transferase from Cylindrocarpon ludium. J Org Chem 61: 7727-7737 (1996)

61. Van der Pyl, Cans DP, Debernard JJ, Herman Lelievre FY, Tahraoui L, Vuilhorgne M, Leboul J. RPR113228, a novel farnesyl protein transferase inhibitor produced by Chrysosporium lobatum. J Antibiot 48: 736-727 (1995)

62. Phife DW, Patton RW, Berrie RL, Yarborough RP, Mohindar SP, Patel M, Bishop WR, Coval SJ. Sch 58450: a novel farnesyl-protein transferase inhibitor possessing 6a,12a:7,12-diepoxybenz[a]anthracene ring system. Tetrahedron Lett 36: 6995-6998 (1995)

63. Jayasuriya H, Bills GF, Cascales C, Zink DL, Goetz MA, Jenkins RG, Silverman KC, Lingham RB, Singh SB. Oreganic acid: A potent novel inhibitor of Ras farnesylprotein transferase from an endophytic fungus. Bioorg Med Chem Lett 6: 2081-2084 (1996)

64. Silverman KC, Jayasuriya H, Cascales C, Vilella D, Bills GF, Jenkins RG, Singh SB, Lingham RB. Oreganic acid, a potent inhibitor of Ras farnesyl-protein transferase. Biochem Biophys Res Commun 232: 478-481 (1997)

65. Dabrah TT, Harwood Jr HJ, Huang LH, Jankovich ND, Kaneko T, Li J-C, Lindsey S, Moshier PM, Subashi TA, Therrien M, Watts PC. CP-225,917 and CP-263,114, novel Ras farnesylation inhibitors from unidentified fungus. I. Taxonomy, fermentation, isolation, and biochemical properties. J Antibiot 50: 1-7 (1997)

66. Chu M, Mierzwa R, Barrabee E, King A, Hallade M, Terracciano J, Patel MG, Patton R, Bishop WR, Puar MS. Sch 207278: a novel farnesyl-protein transferase inhibitor from an unidentified fungus. Biorg Med Chem Lett 7: 2547-2550 (1997)

67. Jayasuriya $H$, Silverman KC, Zink DL, Jenkins RG, Samchez M, Pelaez F, Vilella D, Lingham RB, Singh SB. Clavaric acid: a triterpenoid inhibitor of Ras farnesyl-protein transferase from Clavariadelphus trucatus. J Nat Prod 61: 1568-1570 (1998)

68. Singh SB, Zink DL, Wllims M, Polishook JD, Sanchez M, Silverman KC, Lingham RB. Kanpanols: novel Ras 
farnesyl-protein transferase inhibitors from Stachybotrys kampalensis. Bioorg Med Chem Lett 8: 2071-2076 (1998)

69. Hara M, Soga S, Itoh M, Shono K, Eishima J, Mizukami T. UCH116, new inhibitors of farnesyltrnsferase produced by Strepromyces. J Antibiot 53: 720-723 (2000)

70. Ishii T, Hayashi K, Hida T, Yamamoto Y, Nozaki Y. TAN-
1813, a novel Ras-farnesyltransferase inhibitor produced by Phoma sp. Txonomy, fermentation, isolaton and biological activities in vitro and in vivo. J Antibiot 53: 765-778 (2000)

71. Bergy ME. Kalafungin, a new broad spectrum antibiotic isolasion and characterization. J Antibiot 21: 454-457 (1968) 